Олександра ОВСЯННІКОВА-ТРЕЛЬ, orcid.org/0000-0002-1969-5530 кандидат мистецтввознавства, дочент кафедри історії музики та музичної етнографії Одеської національної музичної академії імені А. В. Нежданової (Oдеса, Україна) alex1973@i.ua

\title{
ХОРОВИЙ СТИЛЬ ДЖ. РАТТЕРА В КОНТЕКСТІ СТИЛЬОВОЇ КОНЦЕПЦІЇ «НОВОЇ ПРОСТОТИ»
}

У статті обговорюється стильова специифіка відомого твору видатного представника сучасної хорової музики Дж. Раттера з позицій індивідуально-композиторського трактування «нової простоти» як філософської та естетичної кониепиії професійної музичної творчості останньої третини XX-початку XXI ст. Простота хорових опусів британського композитора зумовлена композиторською установкою, яка заперечує створення «нової» хорової музики й винахід будь-якої індивідуальної техніки хорового письма. Для хорового стилю Дж. Раттера показовий певний тип композиторської установки, щзо зумовлює його індивідуальну специфіку: композитор іде иляхом «відмови від новизни», його музична мова складається з опорою на онтологічні підстави літургійного жанру й стилістику хорової музики Нового часу. Ця установка Дж. Раттера реалізується в його хорових опусах на двох основних рівнях - вербально-текстовому й музично-семантичному. Композитор спирається на класичні традииї західноєвропейського хорового письма, щзо склалися в надрах иерковної культури й стали основою подальшої професійної композиторської творчості. Відзначимо, щчо хоровий стиль Дж. Раттера складається з опорою на традииії католицького богослужбового жанру.

У такому випадку йдеться про смислове «переінтонування» канонічної жанрової моделі «від музики иерковної - до музики духовної», зверненої до ліричного переживання сакрального й трансцендентного досвіду, яка робить доступними й простими Вічні Істини людського існування. Зазначені якості хорової музики Дж. Раттера зумовлені не тільки ї̈ релігійними джерелами, а й тими світоглядними й стильовими орієнтирами європейського музичного академізму на межі XX-XXI cm., які викликали до життя феномен «нової простоти»в професійній композиторській творчості.

Такий ракурс розгляду хорової музики Дж. Раттера дозволяє осмислити ї̈ з боку симптоматичних явищ професійного музичного мистеитва на межі XX-XXI cm. Крім того, звернення до творчої спадщини живого класика сучасного хорового мистечтва ставить собі за мету заповнення маловивченої в украӥнському музикознавстві проблематики національної своєрідності хорової творчості сучасних композиторів Великої Британії, щзо може послужити теоретичним імпульсом для його практичного виконавського освоєння.

Ключові слова: «простий» стиль, «нова простота», композиторська установка, індивідуальний стиль, хоровий стиль, літургічний жанр, жанрова традииія.

Oleksandra OVSIANNIKOVA-TREL, orcid.org/0000-0002-1969-5530 Candidate of Art History, Associate Professor at the Department of History of Music and Musical Ethnography Odessa National A. V. Nezhdanova Music Academy

(Odessa, Ukraine) alex1973@i.ua

\section{J. RUTTER'S “MAGNIFICAT” IN THE CONTEXT OF THE STYLE CONCEPT OF "NEW SIMPLICITY"}

The worldwide recognition of J. Ratter's choral music is not least due to the "classic" individual composer style, which was formed in reliance on the centuries-old traditions of choral art in Western Europe and the national heritage of English choral culture. The clarity and harmony of J. Rutter's numerous choral opuses is attractive for both performers and listeners because of the accessibility of "form and content", which, in the context of a radical renewal of the musical language by the academic avant-garde in the middle of the 20th century, serves as a kind of comfort in terms of lost opportunities for aesthetic and ethical experience of music. For J. Rutter's choral style, a certain type of compositional attitude is indicative, which determines its individual specificity: the composer follows the path of "rejection of novelty", his musical language is based on the ontological foundations of the liturgical genre and stylistic music of modern times. This attitude of J. Rutter is realized in his choral opuses on two main levels - verbal-textual and musical-semantic. The composer is based on the classical traditions of Western European choral writing, which developed in the depths of 
church culture and became the basis for further professional composition. Note that the choral style of J. Rutter is based on the traditions of the Catholic liturgical genre.

In this case we are talking about the semantic "re-intonation" of the canonical genre model "from church music to spiritual music", addressed to the lyrical experience of sacred and transcendent experience and therefore makes available and simple Eternal Truths of human existence. These qualities of J. Rutter's choral music are conditioned not only by its religious sources, but also by those ideological and stylistic guidelines of European musical academy at the turn of the XX-XXI centuries, which brought to life the phenomenon of "new simplicity" in professional composition. The genre-style indicators of the music by J. Ratter are caused not only by its religious origins, but also by the worldview and style guidelines of European musical academism at the turn of the 20th and 21st centuries, which brought to life the phenomenon of "new simplicity" in professional composer creativity. The ideas of "new simplicity" proclaimed in the 1970s and 80s. Western musical academism (mainly German) reflected the desire to restore the lost meanings and possibilities of the musical language by changing the intellectual and structural principle that defines the essence of the musical composition that dominated the academic vanguard of the middle of the 20th century to emotional, which was expressed in the characteristic definition of this tendency as "new sincerity", the essence of which was the "rehabilitation" of the lyrical-confessional discourse of composer creativity.

Key words: "simple” style, "new simplicity”, composer, individual style, choral style, liturgical genre, genre tradition.

Постановка проблеми. Хорова музика сучасних британських композиторів нині надзвичайно популярна в європейській професійній виконавській практиці, твори провідних представників хорового мистецтва Великої Британії другої половини XX - початку XXI ст. (Дж. Раттера, Дж. Тавенера, К. Дженкінса) все частіше звучать на концертній естраді, фестивалях хорового мистецтва, всіляких конкурсах і тому подібне. Особливе місце в репрезентації своєї національної традиції належить Дж. Раттеру - композитору, що гідно представляє сучасну хорову культуру Великої Британії, відомому як в Європі, так і в Америці, який міцно затвердився в статусі живого класика сучасного хорового мистецтва й нової духовної музики.

Таке визнання його творчості не в останню чергу зумовлено «класичністю» індивідуального композиторського стилю, який сформувався 3 опорою на багатовікові традиції хорового мистецтва Західної Європи й національну спадщину англійської хорової культури. Ясність і гармонійність численних хорових опусів Дж. Раттера приваблива як для виконавців, так і для слухачів через доступність «форми й змісту», яка в контексті радикального оновлення музичної мови, здійсненого академічним авангардом у середині XX ст., виконує функцію своєрідної розради в плані втрачених можливостей естетичного й етичного переживання музики. Простота хорових опусів британського композитора, безумовно, випливає з композиторської установки, що заперечує створення нової хорової музики й винахід будь-якої індивідуальної техніки хорового письма: він знаходить в історичному минулому західноєвропейської хорової музики більш ніж достатні резерви для актуалізації духовних смислів людського буття. I основним із цих резервів для Дж. Раттера є літургійні жанри, які закономірно перетинаються 3 простотою стилю композитора через свій онтологізм, про який свого часу писав П. Флоренський: «<...> можна сказати, чим онтологічнішим $\epsilon$ бачення, тім загальнолюдянішою $€$ форма, якою воно виражено, подібно до того, як священні слова про саме таємниче - найпростіші $<. .>$ Канонічна форма - це форма найбільшої природності й простіше чого не придумаєш, тоді як відступи від форм канонічних боязкі й штучні $<. .>\gg$ (Флоренський, 2001: 561-562).

Незважаючи на очевидну актуальність творчих установок Дж. Раттера для сучасного стильового контексту європейського музичного професіоналізму, який часто оцінюють як «кінець часу композиторів» (В. Мартинов) або ж як епоху «нової анонімності автора» (В. Сильвестров), осмислення творчості Дж. Раттера в зазначеному аспекті практично не представлено в українському музикознавстві, що зумовлено відсутністю інтересу до музичної творчості композиторів Великобританії в цілому. Виконавська практика в такому випадку значно випереджає теоретичні рефлексії жанрово-стильової своєрідності творів композитора. «Магніфікат» Дж. Раттера в такому сенсі $є$ досить репрезентативним зразком «простого» стилю британського композитора й досить популярним твором у сучасному виконавському середовищі.

Аналіз досліджень. Проблема стильової своєрідності хорової музики Дж. Раттера не так часто викладається в сучасних музикознавчих дослідженнях, що пов'язано з відсутністю інтересу вітчизняних музикознавців до хорової музики Великої Британії другої половини XX - перших десятиліть XXI ст. у цілому. Ймовірно, закритість британського хорового мистецтва для українського музикознавства пов'язана з такою ж закритістю творчості композиторів Великої Британії післявоєнного покоління для вітчизняних виконавців: нині можна говорити лише про фрагментарний характер виконавського інтересу до такої 
національної традиції, який залишає «за бортом» практичного освоєння різноманітність індивідуально-композиторських концепцій хорової музики, представлених широкою жанрово-стильовою панорамою.

Національно-стильова специфіка творчості Дж. Раттера й композиторські принципи спадкування традицій західноєвропейського хорового мистецтва стали об'єктом дисертаційного дослідження Ю. Кучурівського, присвяченого побутуванню жанрової традиції латинського реквієму у творчості сучасних композиторів Великої Британії (Кучурівський, 2019). Короткі відомості про творчу постать Дж. Раттера в контексті еволюції християнської музики міститися у відомій праці Е. Вілсона-Діксона (Уілсон-Діксон, 2001), яка представляє найбільш концептуальну оцінку хорової творчості композитора в порівнянні iз численними критичними відгуками (англомовними в більшості своїй), що містяться на доступних інтернет-ресурсах. Філософсько-естетичні й музикознавчі аспекти «простого» стилю як симптоматичного явища європейської композиторської творчості на межі XX - XXI ст. розглядалися В. Мартиновим, В. Сильвестровим, М. Катунян, М. Булошніковим, В. Грачовим, М. Гайковіч, О. Токун, Н. Ручкіною. Деякі параметри індивідуального стилю Дж. Раттера в їх співвіднесеності зі стилістикою «нової простоти» були розглянуті в зазначеній дисертації Ю. Кучурівського.

Мета статті полягає у визначенні основних жанрово-стильових параметрів твору Дж. Раттера, які у своїй художній цілісності втілюють творчу установку британського композитора на «простий» стиль.

Виклад основного матеріалу. Як справедливо зазначає у своїй дисертації Ю. Кучурівський, «імена наступних за Б. Бріттеном композиторів, які представляють нове покоління композиторської школи Великобританії, досі залишаються в тіні свого великого попередника. I це цілком зрозуміло загальновизнаним статусом класика XX століття, що закріпився за ім'ям Б. Бріттена» (Кучурівський, 2019: 110). Ця обставина зумовлена вельми скромними уявленнями сучасних українських виконавців про твори таких авторів, як Дж. Раттер, який в європейському музичному світі давно завоював визнання та статус найбільшого Майстра хорового мистецтва сучасності.

Хорова спадщина британського композитора широко представлена як творами великої форми, так і мініатюрами. Серед найбільш масштабних духовних творів можна відзначити Gloria (1976 рік), Requiem (1985 рік), Magnificat
(1990 рік), Psalfest (1993 рік) та один із останніх творів, написаних композитором, - Feel the Spirit (після 1996 рік). Хорові мініатюри містять різдвяні мотети, народні пісні для подвійного хору й чотири збірки із серії «Різдвяні пісні для хору». Слід зазначити, що в 1988 році Дж. Раттер стає Почесним членом Спілки музикантів духовної музики, а в 1996 році за значний внесок у розвиток духовної музики Архієпископом Кентерберійським йому було присвоєно ступінь Доктора музики.

Крім композиторської, музично-просвітницької та виконавської діяльності, Дж. Раттер відомий як автор музично-теоретичних і музичноісторичних праць: «Оксфордські хорові класики», «Оперні хори» (1995 рік) та «Свропейська духовна музика» (1996 рік), що свідчить про широкий діапазон його творчої особистості.

Основна маса хорових творів британського композитора $є$ його авторськими інтерпретаціями канонічних жанрів, сформованих у лоні богослужбових традицій західного християнства. Звернення Дж. Раттера до літургійних жанрів католицької церкви представляє індивідуальне трактування богослужбової музики, яка органічно пов'язана 3 національними джерелами музичної стилістики творів: майже всі роботи Дж. Раттера призначені для хорів і сягають корінням у хорову практику англіканської церкви, яка фігурує в його житті із самого дитинства. «Я люблю Англіканську церкву, - каже композитор, - коли я звертаюся до священного тексту, я відчуваю його всім серцем. Але я більше прихильник, ніж конкретний вірянин» (Macfarlane, 2016). Яскравим підтвердженням цієї творчої позиції є всі його масштабні хорові твори - «Глорія» (1974 рік), «Реквієм» (1985 рік), «Магніфікат» (1990 рік) і «Меса дітей» (2003 рік), які нині виконуються повсюдно, особливо в Сполучених Штатах, де у всіх чотирьох творів були свої прем'єри. «Реквієм» Дж. Раттера використовувався на меморіальних службах у Нью-Йорку після теракту 11 вересня 2001 року, а пізніше цей же твір звучав на похоронах колишнього канцлера Німеччини Гельмута Коля. Також у Токіо $є$ хор “JR Singers”, присвячений творчості британського автора. Ці факти вказують на визнання композитора у світовому масштабі й високий статус його музики.

Дж. Раттера часто дорікають у доступності й простоті його мелодійної музики, яка «позбавляє його місця в пантеоні серйозних композитоpiв» (Macfarlane, 2016). «Коли я згадав його ім'я модерністському композитору й диригенту П'єру Булезу в інтерв'ю кілька років тому, відповіддю було лише пирхання», - зазначає критик (там 
само). Ці докори пов'язані з характерною рисою стилю композитора, що бере свої джерела в національній хоровій культурі й пов'язана 3 традицією аматорського хорового виконавства. «Коли ви пишете для хорів, ви пишете, як правило, для любителів, - каже композитор - тому потрібна певна простота, і я з радістю приймаю це. Особливо в різдвяній музиці, яка призначена для простих і звичайних людей. I тут ви залишаєте свій модний смак на порозі, якщо хочете щось із цього витягти» (White, 2014).

Інша поширена критика хорових творів Дж. Раттера полягає в тому, що вони є вторинними, але композитор без всякого збентеження оголошує свої джерела натхнення: в основному це Б. Бріттен, У. Уолтон, Г. Форе, музика Бродвею. «Ви можете додати до цього Равеля $<. .>$ Я ніколи ні від кого свідомо нічого не приховував, але композитори, як правило, або дослідники, або сороки, і я останній. Я не збираюся відкривати нові можливості. Мій дар, якщо він у мене $\epsilon,-$ це взяти те, що в повітрі, й використовувати його» - говорить із цього приводу композитор (Macfarlane, 2016).

Водночас мало хто може заперечувати, що у своїх кращих творах, таких як, наприклад, різдвяна пісня "What Sweeter Music", яку будуть співати тисячі хорів у святковий сезон, виявляється бездоганна майстерність та особливий мелодійний дар Дж. Раттера, якому більшість композиторів позаздрить. I його музика зачіпає почуття людей так, як це не робить більшість сучасної класичної музики. I це, ймовірно, можна пояснити релігійними джерелами його творчості. Однак, незважаючи на те, що композитор буквально занурений у християнство у своїй творчій діяльності, його особисті переконання, за його власним твердженням, «вельми туманні» (White, 2014).

Зазначені якості хорової музики Дж. Раттера зумовлені не тільки іiі релігійними джерелами, а й тими світоглядними й стильовими орієнтирами європейського музичного академізму на межі XX - XXI ст., які викликали до життя феномен «нової простоти» в професійній композиторській творчості. Ідеї «нової простоти», проголошені в 1970-80-х рр. в західному музичному академізмі, відбивали прагнення повернути втрачені смисли й можливості музичної мови шляхом «зміни інтелектуального й структурного принципів, які визначають суть музичної композиції, що панувала в академічному авангарді середини XX ст., на емоційний» (Ручкіна, 2017: 324), що виразилося в характерному визначенні цієї тенденції як «нова щирість», суть якої полягала в «реабілітації» лірико-сповідального дискурсу композиторської творчості. Н. Ручкіна наводить такі визначення «нової простоти», які зумовлені конкретними типами композиторських установок на художню реалізацію концепції «простої» музики: простота як «спрощення» (показова для стилістики творів В. Рима й А. Шнітке й вказує на спрощеність в порівнянні з музичною мовою авангардних опусів 1970-80 рр.), простота як втілення філософії мінімалізму (бріколажна техніка В. Мартинова, наприклад), простота як «аскетизм» (найяскравіше представлена так званим сакральним мінімалізмом А. Пярта, Х. Гурецького й Дж. Тавенера), простота як «відмова від нового» (концепції музичної творчості В. Мартинова, В. Сильвестрова, І. Соколова, Г. Пелеціса) (Ручкіна, 2017).

Характерними рисами «нової простоти» як напряму професійної композиторської творчості $\epsilon$ активне звернення до жанрово-стильових канонів минулих епох, принцип спрощення музичної мови (що дозволяє дослідникам проводити паралелі 3 мінімалістською технікою, але не вказує на принципову тотожність цих двох музичних стилів), культивування мелодійних і гармонійних формул як основних елементів музичної виразності.

Один із найвідоміших хорових творів Дж. Раттера «Магніфікат» (1990 рік) є досить показовим у плані індивідуального композиторського розуміння зазначеної вище тенденції «спрощення» музичного мистецтва. Музикознавець Дж. Бауден зазначає, що твір Раттера має кілька спільних рис iз «Магніфікатом» I. С. Баха: обидва повторюють матеріал першої частини в останній, використовують мелодії хоралів, присвячують «більш рефлексивні вірші» солісту й вставляють додатковий текст, пов'язаний із Різдвом, у тексти католицького богослужбового жанру (Bawden, 2014).

«Магніфікат» був створений композитором на замовлення MidAmerica Productions, концертної організації в Нью-Йорку, яка виступає в Carnegie Hall iз хором із 200 голосів, відібраних у Сполучених Штатах. Монументальність вокально-хорової партитури в цьому плані звичайно ж співвідносна $з$ традиціями латинської літургійної хорової музики, які присутні у творі британського автора й на рівні текстової основи «Магніфікату», й на рівні принципів організації хорової партитури.

Розглянемо ці два рівні. Перша частина заснована на традиційній для жанру магніфікату канонічній текстовій основі, пов'язаній із Богородичною тематикою. У другій частині свого твору композитор звертається до традиційної англійської різдвяної пісні. За свідченням самого автора, він був натхненний урочистістю релігійних свят на честь діви Марії в латиноамериканських куль- 
турах і задумував Магніфікат як «яскраву фієсту 3 ароматом латіни» (Macfarlane, 2016). Тому на додаток до літургійного латинського тексту він обрав вірш XV ст., в якому Діва Марія порівнюється з трояндою («Троянди, чарівної Троянди»). «3 часів Баха, - говорить Дж. Раттер, - музичних творів, які давали б розширене розуміння текстової основи католицького богослужіння, на диво не так багато. Я давно хотів написати розширений Магніфікат, але не знав, як до нього наблизитися, поки не знайшов свою відправну точку у зв'язку 3 текстом про Діву Марію. У таких країнах, як Іспанія, Мексика й Пуерто-Рико, святкові дні Діви - це радісні можливості для людей вийти на вулиці й відсвяткувати зі співом, танцями й процесіями. Ці образи святкування на відкритому повітрі були, я думаю, десь у моїй голові, коли я писав, хоча я до кінця не усвідомлював цього факту. Я усвідомлював, що йду прикладом Баха, додаючи до літургійного тексту прекрасний старий англійський вірш про троянду й молитву до святої Mapiï» (Macfarlane, 2016).

Композитор використовує традиційний символ квітки, котру з перших століть християнства пов'язували з Богородицею, в якій $є$ багато різних символічних найменувань, і серед них - Роза Таємнича (Бауер, 1995). У католицтві, як відомо, троянда $є$ головним символом Діви Марії. Текст третьої, четвертої, п’ятої та шостої частин також відповідає канонічному латинському тексту магніфікату. А завершальна сьома частина твору використовує канонічний католицький текст, що не належить до такого жанру: він являє собою широко вживане звернення до Пресвятої Трійці ("Gloria Patri, et Filio, et Spiritui Sancto. Sicut erat in principio, et nunc, et semper, et in saecula saeculorum. Amen": «Слава Отцю, і Сину, й Святому Духу, й нині, й повсякчас, і на віки віків»). Як бачимо, композитор не використовує весь обсяг канонічного тексту католицького Магніфікату, він обирає лише деякі його рядки, які пов'язані з образами радісного вихваляння імені Всевишнього.

Крім того, виключаючи третій рядок тексту магніфікату, в якій йдеться про смиренний образ Діви Mapiï ("quia respexit humilitatem ancillae suae, ecce enim ex hoc beatam me dicent omnes generationes": «Що зглянувся Він на покору Своєї раби, бо відтепер будуть догоджати Мене всі роди»), й замінюючи його на текст англійської різдвяної пісні в другій частині свого твору, в якій образ Діви Марії порівнюється 3 прекрасною трояндою, композитор змінює сакральний сенс жанру, «розгортаючи» його в сторону суб' єктивно-ліричного вираження. Таким чином «знижується» релігій- ний пафос богослужіння та на перший план виходить простота й доступність образів поетичного тексту й експресія музичної інтонації, що озвучує їх у кращих традиціях вокально-аріозності стилю європейської музики.

Що стосується вокально-хорового стилю «Магніфікату», то в ньому композитор спирається на класичні традиції західноєвропейського хорового письма, що склалися в надрах церковної культури й стали основою подальшої професійної композиторської творчості. Відзначимо, що хоровий стиль твору складається 3 опорою на традиції католицького богослужбового жанру: в монументальній композиції переважають найпоширеніші форми ранніх монодичних розспівів віршів магніфікату (responsorium prolixum - чергування хорових рефренів і сольних розспівів, прикрашених мелізмами; tractus - сольний або хоровий жанр, в якому розспів віршів не переривається рефреном; антифон - розспів, обрамлений двома рефренами, на початку й в кінці). У цілому для хорової партитури Дж. Раттера надзвичайно показовий мелодизм, який надає основний ліричний тон музичного висловлювання та особливу естетичну привабливістьтембровоїпалітрихоровогозвучання.

Відзначимо також, що в разі раттеровського «Магніфікату» йдеться про принцип успадкування традицій літургійної хорової музики та їх творче переосмислення в умовах сучасної музичної культури й адаптації до сучасної виконавській практиці. Останнє безпосередньо пов'язане 3 діяльністю непрофесійних хорових колективів, яка широко представлена в Дж. Раттера (композитор активно співпрацює з багатьма авторськими колективами - й в плані керівництва, й в плані створення репертуару). Помітне спрощення музичної мови багатьох хорових партитур Дж. Раттера в порівнянні зі зразками хорової музики класикоромантичного періоду й тим більше $\mathrm{XX}$ століття пов'язують, зазвичай, із традиціями общинного співу англіканської церкви, які сформувалися через досить радикальні реформи богослужбової практики в Англії в XVI - XVII ст.

У «Магніфікаті» Дж. Раттера органічно переплітаються різні вокально-хорові традиції, що йдуть як від католицької, так і від англіканської богослужбової музики. У цьому контексті примітний той факт, що різдвяні пісні й гімни, які $\epsilon$ найпоказовішими для англійської хорової традиції жанру й найпростішими у своїх стильових проявах, часто визначають як основну спеціалізацію композитора. Спадкування своїх національних традицій хорового мистецтва й адаптація їх до сучасних умов побутування церковної 
музики - ось центральна творча й професійна установка композитора, що здобув славу видатного Майстра в міжнародній хоровій спільноті. I, незважаючи на ту обставину, що сам Дж. Раттер не вважає себе релігійною людиною у звичному розумінні, його високий професіоналізм дозволив творчо реалізувати свою приналежність до культурної традиції, яка так чи інакше вплинула на індивідуальне композиторське уявлення про жанрову стилістику магніфікату.

Висновки. Узагальнюючи міркування про специфіку «простого» стилю Дж. Раттера, яскравим зразком якого виступає його «Магніфікат», ми можемо чітко позначити певний тип композиторської установки, що зумовив цю специфіку: композитор йде шляхом «відмови від новизни», його музична мова складається з опорою на онтологічні підстави літургійного жанру й стиліс- тику хорової музики Нового часу. Ця установка Дж. Раттера реалізується у творі на двох основних рівнях - вербально-текстовому й музичносемантичному. У такому випадку йдеться про смислове «переінтонування» канонічної жанрової моделі «від музики церковної - до музики духовної», зверненої до ліричного переживання сакрального й трансцендентного досвіду, яке робить доступними й простими Вічні Істини людського існування.

Позначений ракурс дослідження індивідуального стилю Дж. Раттера дає можливість розширення музикознавчої проблематики відповідно до актуальних тенденцій сучасної композиторської творчості та її діалогічної природи, укладеної в складні взаємодії особистісно-суб'єктивних естетичних принципів і кризи індивідуальної творчості в епоху «кінця часу композиторів».

\section{СПИСОК ВИКОРИСТАНИХ ДЖЕРЕЛ}

1. Бауэр В. Энциклопедия символов. Москва : Крон-Пресс, 1995. 689 с.

2. Кучурівський Ю. Жанрова традиція реквієму у творчості композиторів Великобританії останньої третини XX - початку XXI ст. : автореф. дис. ... канд. мист. : 17.00 .03 «Музичне мистецтво» ; Одеська національна музична академія ім. А. В. Нежданової. Одеса, 2019. 20 с.

3. Ручкина Н. «Новая простота» в музыкальном искусстве XX - начала XXI века. Обсерватория культуры. 2017. T. 14. № 3. C. 322-329.

4. Уилсон-Диксон Э. История христианской музыки. Санкт-Петербург : Мирт, 2001. 428 с.

5. Флоренский П. Иконостас. Павел Флоренский. Христианство и культура. Москва : АСТ ; Харьков : Фолио, 2001. $663 \mathrm{c}$.

6. Bawden J. Magnificat. URL: http://www.choirs.org.uk/prognotes/Rutter\%20-\%20Magnificat.htm (дата звернення: 20.11.2020).

7. Macfarlane A. Interview with John Rutter. Archived from the original on 4 March 2016. Retrieved 18 December 2013. URL: http://www.alanmacfarlane.com/DO/filmshow/rutterl_fast.htm (дата звернення: 19.11.2020).

8. White M. The carol singers' shining star. URL: https://www.telegraph.co.uk/culture/4727014/The-carol-singersshining-star.html (дата звернення: 20.11.2020).

\section{REFERENCES}

1. Bauer, W. (1995). Encziklopedia simvolov. [Encyclopedia of simbols]. Moscow: Kron-Press. 689 p. [in Russian].

2. Kuchurivsky, Yu. (2019). Zhanrova tradicziya rekviemu u tvorchosti kompozitoriv Velikobritanii ostanoi tretini XX - nachala XXI stolit. [Genre tradition of Requiem in the work of composers in Great Britain in the last third of the 20th and beginning of the 21 st centuries]. The abstract to dis.... cand. of art history: specialty 17.00 .03 - Musical art. Odessa [in Ukrainian].

3. Ruchkina, N. (2017). „Novaya prostota” v muzikalnom iskusstve XX-nachale XXI veka. ["New Simplicity” in the musical art of the 20th and early 21 st centuries]. Observatory of Culture. V. 14. No. 3, 322-329 [in Russian].

4. Wilson-Dickson, E. (2001). Istoriya christianskoy muziki. [History of Christian Music]. St. Petersburg: Myrtle. 428 p. [in Russian].

5. Florensky, P. (2001). Ikonostas. [Iconostasis. Pavel Florensky. Christianity and culture]. Moscow: AST; Kharkov: Folio. 663 p. [in Russian].

6. Bawden J. Magnificat. URL: http://www.choirs.org.uk/prognotes/Rutter\%20-\%20Magnificat.htm [in English].

7. Macfarlane A. Interview with John Rutter. Archived from the original on 4 March 2016. Retrieved 18 December 2013. URL: http://www.alanmacfarlane.com/DO/filmshow/rutter1_fast.htm [in English].

8. White M. The carol singers' shining star. URL: https://www.telegraph.co.uk/culture/4727014/The-carol-singers-shining-star.html [in English]. 